relation and while medical schools are oversubscribed there will be limited consumer pressure for improvement. The GMC directives offer a unique opportunity to encourage colleagues to reinvigorate their teaching. The present mood for change should be exploited to allow teacher to talk to teacher, to share ideas, methods and resources; Price and Mitchell have shown that staff value such dialogue. ${ }^{22}$ If teachers approach the task with enthusiasm this might be an infectious disease we would be happy for students to contract while studying child health.

1 Lowry S. What's wrong with medical education in Britain? $B M F$ 1992; 305: 1277-80.

2 Doran GA. Aspects of the content versus process debate in medical education. Med Educ 1984; 18: 401-5.

3 Anderson J, Graham A. A problem in medical education: is there information overload? Med Educ 1980; 14: 4-7.

4 General Medical Council. Tomorrow's doctors. Recommendations on undergraduate medical education. London: mendations on

5 Bennett RJ, Sackett DL, Haynes RB, et al. A controlled trial of teaching critical appraisal of the clinical literature to of teaching critical appraisal of the clinical

6 Barrows HS. Inquiry: the pedagogical importance of a skill central to clinical practice. Med Educ 1990; 24: 3-5.

7 Barrows HS. Problem based, self directed learning. $\mathcal{F} A M A$ 1983; 250: 3077-80.

8 Weinman J. Communication and learning course. In: Towle $\mathrm{A}$, ed. Innovative learning and assessment. London: Kings Fund, 1994: 11-4.
9 Whitehouse C. Developing a basic communication skills course. In: Towle A, ed. Innovative learning and assessment. London: Kings Fund, 1994: 15-6.

10 Cushing A, Joffe T. Clinical and communication skills workbook assignment. In: Towle A, ed. Innovative learning and assessment. London: Kings Fund, 1994: 88-9.

11 Foulds DM, Sterling R, Wood PR, Sterling J, Littlefield JH. The current place of learning objectives in paediatrics. Med Educ 1989; 23: 407-8.

12 Miller $M$. Changing medical education in western Europe. Med Educ 1978; 12 (suppl 2): 28-33.

13 Garrud P, Chapman IR, Gordon SA, Herbert $M$. Nonverbal communication evaluation of a computer assisted learning package. Med Educ 1993; 27: 474-8.

14 Petersen S, Howard L. Student-led organisation of practical time in physiology. In: Towle A, ed. Innovative learning time in physiology. In: Towle A, ed. Innovative lear

15 Taylor D. Peer assessment and presentation skills. In: Towle A, ed. Innovative learning and assessment. London: Kings Fund, 1994: 90-1.

16 Blair M. Innovations in child health teaching. In: Towle A, ed. Innovative learning and assessment. London: Kings Fund, 1994: 37-8.

17 Underwood JCE, Cotton DWK, Cross SS. Interactive compact disc (CD-1) and multimedia for student-centred learning. In: Towle $\mathrm{A}$, ed. Innovative learning and assessment. London: Kings Fund, 1994: 73-4.

18 Rolfe I, McPherson J. Formative assessment: how am I doing? Lancet 1995 ; 345: 837-9.

19 Lawson M, Moss F. The move from inpatient teaching. In: Towle A, ed. Innovative learning and assessment. London: Kings Fund, 1994: 46-9.

20 Fox NJ, Joesbury H, Hannay DR. Family attachments and medical sociology: a valuable partnership for student medical sociology: a valuable part

21 Forster DP, Drinkwater CK, Corradine A, Cowley K. The family study and survey at Newcastle medical school: an integrated approach. Med Educ 1992; 26: 110-5.

22 Price DA, Mitchell CA. A model for clinical teaching and learning. Med Educ 1993; 27: 62-8.

\title{
Core knowledge, skills, and attitudes for undergraduates: kindling curiosity
}

\author{
J D Baum
}

The body of knowledge applicable to the practice of medicine is vast and growing exponentially and there is no possibility, and never was, of teaching the subject comprehensively. Rather, students need to be shown how to find their way to and through the body of knowledge in order to apply it safely to the care of the individual or population concerned. Thus, for the study of paediatrics and child health, undergraduate students need a clear syllabus to define the core knowledge, experience, and skills to be acquired. This should be supported by a basic text, selective additional reading, or the equivalent information in electronic format. The whole needs to be brought to life through contact with clinical teachers, and the clinical drama of the lives of children and their families. The students' attitudes to learning will inevitably be affected by the content and structure of their examinations in paediatrics and child health and how these in turn relate to their graduation prospects.

The agenda for learning and teaching the Health, Royal Hospital for Sick Children, for Sick Children, St Michael's Hill,
Bristol BS2 8BJ

Correspondence to: Professor Baum. medicine of childhood differs slightly but significantly from the medicine of adulthood. In addition to classical anatomy, and the anatomy of the genome, students need to focus on the anatomy of the family and of the society in which the family live. They need to be encouraged to take as much interest in the physical sign of the parent not present at the bedside, of the total family's attendance in the outpatient clinic, of the distress signals of silence or overactivity, as in feeling the tip of an enlarged spleen or demonstrating a positive Babinski reflex.

In these days of the nightmare of health service reforms, it is perhaps surprising and heartening to note the emergence of an immensely important (if obvious) principle, namely that medical education should be lifelong, bridging the great divides of the past, at graduation, at collegiate membership, and consultancy appointment. The essence of continuing medical education for consultants should be no different from the education of undergraduate students of medicine: we have to establish firm but impermanent foundations of core knowledge on which to build a theoretical and applied approach to medical practice drawn from the ever changing technology, language, and database of the clinical sciences. The 'senior' and 'junior' students may then sit and learn together, provided they remain hungry for knowledge. My central concern is 
how to sustain this insatiable appetite which is the driver of lifelong learning.

I have a greater belief in role models than in CD-ROMs. If we can harness from continuing medical education an ethos of consultant led curiosity then students of all ages and stages will remain starry eyed about their vocation. At their best, clinical meetings and ward rounds are stimulants of the learning appetite. If a consultant will go out of her or his way to see an interesting case under another colleague's care on ward 37, then 'junior' students, undergraduates, senior house officers, and registrars will make the trek likewise. Of course we must all see the interesting case as a person and a human and domestic problem in need of our care, but also reflect on the variation and similarity among the common conditions, and the illuminating lessons of the rarity.

From the reforms in higher education, it is emerging that we are to be judged (and funded) on the quality of our undergraduate teaching. I suppose this is to be welcomed. It will at least give status to teaching and even to teachers, provided that the evaluation process does not give birth to another monster paperchase, auditing to death the very practice that we are seeking to enhance. There must be room for the charismatic teacher - the Cliff Roberton, Mary Lindsay, Ronnie Mackeith, Peter Tizard - who, notwithstanding regulations, will set the student's imagination alight, even if we cannot measure how it's done nor define the education outcome.

This brings me back to my critical assumption that good sense will prevail among those writing the core syllabus for our students, juniors, and seniors alike. Putting ideology aside, if there are assessments to be made, then all students will turn to the syllabus on which they are being assessed. We need to be sure that the importance of the clinical consultation, of Winnicott's views on good enough parenting, and of primum non nocere sit alongside blood gas interpretation and the new genetics, in the formal examinations in paediatrics and child health. There must be room at all stages of our education for value to be given to the sense of vocation, of the tradition of the noble physician and the timeless relationship between student and teacher.

'More than the calf needs to suck, so does the mother cow need to give suckle'

Babylonian Talmud (Pesachim 112a) 